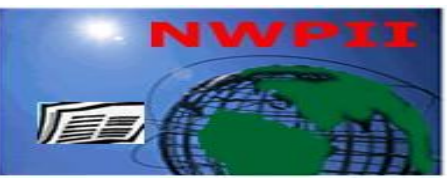

American Journal of Biomedical

Sciences

ISSN: 1937-9080

nwpii.com/ajbms

\title{
In Vitro Transformation of Sol-gel Derived Bioactive Glass from Sand
}

\author{
Luqman A. Adams ${ }^{1 *}$ and Enobong R. Essien ${ }^{2}$ \\ ${ }^{1}$ Department of Chemistry, University of Lagos, Nigeria \\ ${ }^{2}$ Department of Chemical Sciences, Bells University of Technology, Nigeria \\ *Corresponding Author \\ Luqman A. Adams \\ Department of Chemistry \\ University of Lagos \\ Nigeria \\ Email: ladams@unilag.edu.ng.
}

Received: 01 July 2015; | Revised: 23 November 2015; | Accepted: 02 December 2015

\begin{abstract}
A Bioactive glass in the quaternary system $\mathrm{SiO}_{2}-\mathrm{Na}_{2} \mathrm{O}-\mathrm{CaO}-\mathrm{P}_{2} \mathrm{O}_{5}$ was prepared from sand as precursor in place of alkoxysilanes such as tetraethyl orthosilicate (TEOS) and tetramethyl orthosilicate (TMOS). Sodium metasilicate extracted from the sand was processed to a gel via the sol-gel technique. The gel, after aging was dried at lower temperatures before sintering at $950{ }^{\circ} \mathrm{C}$ for $3 \mathrm{~h}$ to form $\mathrm{Na}_{2} \mathrm{Ca}_{2} \mathrm{Si}_{3} \mathrm{O}_{9}$ crystals for enhanced mechanical property. The glass monolith was then subjected to standard in vitro bioactivity study in simulated body fluid (SBF) over 0-21 days. Characterization of the samples before and after immersion in SBF were performed using mechanical tester, scanning electron microscopy (SEM), energy dispersive X-ray (EDX), X-ray diffraction and Fourier transform infrared (FTIR) to evaluate compression strength, morphology, composition, diffraction patterns and chemical bonding respectively. The compression strength of the glass was $1.77 \mathrm{Mpa}$. The major crystalline phase was $\mathrm{Na}_{2} \mathrm{Ca}_{2} \mathrm{Si}_{3} \mathrm{O}_{9}$ which, however, transformed to an amorphous phase in SBF while forming hydroxyapatite (HA) and hydroxycarbonate apatite (HCA). The material may be a useful candidate in the regeneration of trabecular bones.
\end{abstract}

Keywords: Silica source; $\mathrm{Na}_{2} \mathrm{Ca}_{2} \mathrm{Si}_{3} \mathrm{O}_{9}$; Compression strength; Trabecular bone; Hydroxycarbonate apatite.

\section{Introduction}

Synthetic bioactive glasses are unique for eliciting bone-bonding reactions when used in vivo and in vitro making them attractive materials for restoration of damaged or diseased tissues and bones. Consequently, effort is ongoing towards developing suitable glass materials tailored to achieve the main features for ideal bone tissue engineering scaffolds [1-6]. Biological compatibility, appropriate mechanical strength and osteointegration properties are vital for optimal performance which should culminate in formation of hydroxycarbonated apatite HCA [69].

While formation of HCA layer is considered to be a useful step in bone regeneration process, other key factors include: critical concentrations 
of dissolution products from silicate-based bioactive glasses and gene expression [10-13].

Glasses based on Hench's 45S5 composition [14-16] have been widely studied for their mechanical properties and concomitant in vivo and in vitro bioactivity in relation to surface reactivity in body fluids. There are still challenges regarding mechanical properties, biodegradation and bioactivity [17-19].

For glasses containing $\mathrm{Na}_{2} \mathrm{O}$ in the composition, sintering leads to the formation of $\mathrm{Na}_{2} \mathrm{Ca}_{2} \mathrm{Si}_{3} \mathrm{O}_{9}$ crystalline phase which significantly improves their mechanical strength, while transforming to amorphous hydroxyapatite (HA) in SBF [6,20-23]. Significantly, those efforts have utilised tetraethyl orthosilicate [TEOS] as precursor [6,8,20-22]. Our aim in this work, therefore, is to use sand as a cheap silica source to obtain bioactive glass in the quaternary system $\mathrm{SiO}_{2}-\mathrm{Na}_{2} \mathrm{O}-\mathrm{CaO}-\mathrm{P}_{2} \mathrm{O}_{5}$ and evaluate the transformation of the crystalline $\mathrm{Na}_{2} \mathrm{Ca}_{2} \mathrm{Si}_{3} \mathrm{O}_{9}$ phase formed in simulated body fluid.

\section{Materials and methods}

\subsection{Materials}

The sand used as starting material was obtained from Ifo in Ogun State, South-West Nigeria and had a composition shown elsewhere [23]. Analytical grade reagents were used as obtained: $\mathrm{NaNO}_{3}$ (Sigma-Aldrich, 99\%), $\mathrm{Ca}\left(\mathrm{NO}_{3}\right)_{2} \cdot 4 \mathrm{H}_{2} \mathrm{O}$ (Loba Chemicals, 98\%), $\mathrm{H}_{3} \mathrm{PO}_{4}$ (Sigma-Aldrich, 85\%) and $\mathrm{HNO}_{3}$ (RiedelDeHaën, 60\%) to synthesize the bioactive glass. $\mathrm{NaCl}, \quad \mathrm{NaHCO}_{3}, \quad \mathrm{KCl}, \quad \mathrm{K}_{2} \mathrm{HPO}_{4} \cdot 3 \mathrm{H}_{2} \mathrm{O}$, $\mathrm{MgCl}_{2} \cdot 6 \mathrm{H}_{2} \mathrm{O}, \quad \mathrm{CaCl}_{2}$, trishydroxymethyl aminomethane [Tris-buffer, $\left(\mathrm{CH}_{2} \mathrm{OH}\right)_{3} \mathrm{CNH}_{2}$ ] and $1 \mathrm{M} \mathrm{HCl}$ used to prepare $\mathrm{SBF}$ were purchased from Sigma-Aldrich.

\subsection{Preparation of bioactive glass}

The procedure for preparing the glass with composition (mol \%) $46.99 \mathrm{SiO}_{2}-24.36 \mathrm{Na}_{2} \mathrm{O}-$ $25.50 \mathrm{CaO}-3.15 \mathrm{P}_{2} \mathrm{O}_{5}$ is a modification of Chen et al.'s [22] method of synthesizing sol-gel Bioglass ${ }^{\circledR}$ 45S5. Briefly, sodium metasilicate, obtained from the sand through a procedure reported previously [23], was added slowly to stirred $0.05 \mathrm{M} \mathrm{HNO}_{3}$ and allowed for $1 \mathrm{~h}$ to complete the hydrolysis. Afterwards, to the mixture, $\mathrm{NaNO}_{3}, \mathrm{H}_{3} \mathrm{PO}_{4}$ and $\mathrm{Ca}\left(\mathrm{NO}_{3}\right)_{2} \cdot 4 \mathrm{H}_{2} \mathrm{O}$ were added sequentially for which molar ratio of water to all the four reagents were fixed at 20 . Each reagent was allowed to react for $45 \mathrm{~min}$ after each addition. Thereafter, the final mixture was stirred for additional $1 \mathrm{~h}$ before transferring the resulting sol into teflon moulds and kept at room temperature for $72 \mathrm{~h}$. The gel obtained was heated at as follows; $70^{\circ} \mathrm{C}$ for $72 \mathrm{~h}, 130^{\circ} \mathrm{C}$ for 42 $\mathrm{h}, 700^{\circ} \mathrm{C}$ for $2 \mathrm{~h}$ and $950^{\circ} \mathrm{C}$ for $3 \mathrm{~h}$ to age, dry, stabilize and sinter respectively. The heating and cooling rate was maintained at $5^{\circ} \mathrm{C} / \mathrm{min}$.

\subsection{Characterization}

The density $\rho_{\text {glass }}$ of the bioactive glass was determined from the mass and dimensions of the sintered body. The porosity $P$ was calculated by

$$
P=\left(1-\frac{\rho_{\text {glass }}}{\rho_{s}}\right) \times 100
$$

where density $\rho_{\mathrm{s}}=2.7 \mathrm{~g} / \mathrm{cm}^{3}$ is the theoretical density of 45S5 Bioglass $®$ [24].

The microstructure of the glass was characterized in a EVO/MAIO scanning electron microscope (SEM) equipped with energy dispersive X-ray analyzer (EDX) before and after immersion in simulated body fluid (SBF) for a maximum of 21 days. The samples were carboncoated and observed at an accelerating voltage of $15 \mathrm{kV}$.

Samples were characterized using X-ray diffraction (XRD) analysis after sintering and after each immersion experiment in SBF to investigate the glass phases present. The samples were first ground to powder, then $0.1 \mathrm{~g}$ of powder was measured in a PANalytical Empyrean X ray diffractometer using $\mathrm{CuK} \alpha$ radiation source of wavelength $(\lambda)=0.154056 \mathrm{~nm}$ operated at $40 \mathrm{kV}$ and $40 \mathrm{~mA}$ to obtain the diffraction patterns in the $2 \theta$ range from $5^{\circ}-90^{\circ}$.

Fourier transform infrared (FTIR) spectroscopy was performed in a Shimadzu $8400 \mathrm{~S}$ spectrometer with wavenumber range of $4000-400 \mathrm{~cm}^{-1}$ employing $\mathrm{KBr}$ pellets in a reflectance mode with a $4 \mathrm{~cm}^{-1}$ resolution to 
monitor the nature of chemical bonds present in the samples.

\subsection{Measurement of mechanical Strength}

The compression strength of the sintered bioactive glass was measured using a Testometric OL11 INR (Lancashire, England) mechanical tester at crosshead speed of $0.5 \mathrm{~mm} / \mathrm{min}$. The samples were cylindrical in shape with dimensions $12 \mathrm{~mm}$ x $24 \mathrm{~mm}$ (diameter x height). During the compression test, the load was applied until densification commenced. The compression strength was determined using the relation:

$$
\sigma_{\mathrm{c}}=\mathrm{F} / \square \mathrm{r}^{2}
$$

where $\sigma_{\mathrm{c}}$ is the compression strength, $\mathrm{F}$ is the applied load at failure and $\mathrm{r}$ is the sample radius.

\subsection{In vitro bioactivity test in simulated body fluid}

Assessment of bone bonding ability was performed using the standard in vitro procedure
[25]. The acellular simulated body fluid (SBF) was prepared using analytical grade reagents: $\mathrm{NaCl}, \quad \mathrm{NaHCO}_{3}, \quad \mathrm{KCl}, \quad \mathrm{K}_{2} \mathrm{HPO}_{4} \cdot 3 \mathrm{H}_{2} \mathrm{O}$, $\mathrm{MgCl}_{2} \cdot 6 \mathrm{H}_{2} \mathrm{O}, \quad \mathrm{CaCl}_{2}$, trishydroxymethyl aminomethane [Tris-buffer, $\left(\mathrm{CH}_{2} \mathrm{OH}\right)_{3} \mathrm{CNH}_{2}$ ] and $1 \mathrm{M} \mathrm{HCl}$ with ions concentrations shown in Table 1. Samples were immersed in the SBF solution at a concentration of $0.01 \mathrm{~g} / \mathrm{ml}$ in clean sterilised plastic bottles, which were initially washed using $\mathrm{HCl}$ and deionized water. The bottles were placed inside a thermostated incubator at a temperature of $36.5{ }^{\circ} \mathrm{C}$ at an initial $\mathrm{pH}$ of 7.4. The SBF solutions were not refreshed throughout the period of immersion to monitor $\mathrm{pH}$ of the solution daily for 14 days using a $\mathrm{pH}$ meter (Hanna, HI96107). The samples were extracted from the SBF solution after 7, 14 and 21 days respectively, rinsed with deionized water and left to dry at ambient temperature in a desiccator. Formation of apatite layer on the glass surface was monitored by SEM, EDX, XRD and FTIR.

Table 1: Ion concentrations ( $\mathrm{mM}$ ) in human plasma in comparison with SBF

\begin{tabular}{lcccccccc}
\hline Ion & $\mathrm{Na}^{+}$ & $\mathrm{K}^{+}$ & $\mathrm{Mg}^{2+}$ & $\mathrm{Ca}^{2+}$ & $\mathrm{Cl}^{-}$ & $\mathrm{HCO}_{3}^{-}$ & $\mathrm{HPO}_{4}{ }^{2-}$ & $\mathrm{SO}_{4}{ }^{2-}$ \\
\hline SBF & 142.0 & 5.0 & 1.5 & 2.5 & 147.8 & 4.2 & 1.0 & 0.5 \\
$\begin{array}{l}\text { Human } \\
\text { Plasma }\end{array}$ & 142.0 & 5.0 & 1.5 & 2.5 & 103.0 & 27.0 & 1.0 & 0.5 \\
\hline
\end{tabular}

\section{Results and discussion}

\subsection{Mechanical strength of the glass}

The force-deflection curve obtained from compression test performed on the sintered sample is shown in Figure 1. As observed, four major stages are visible. In the first stage, A, the material maintains a positive slope until a maximum stress is reached, then decreases temporarily due to cracking of the pore struts and closing up of the micropores, stage B. This regime is followed by stage $\mathrm{C}$, where the forcedeflection curve rises again as material shows ability to bear higher load due to densification of the pores as more stress is applied on the material [21]. Finally, the material collapses completely under maximum stress, which is in agreement with general findings on the strength value of porous ceramics [8]. The glass under this study exhibited a compression strength of $1.77 \mathrm{MPa}$ and a porosity of $77 \%$. This result is comparable to the compression strength of spongy bone (not the strut) which is in the range of $0.2-4 \mathrm{MPa}$ [26]. Mechanical strength of spongy or trabecular bone is in the range $0.1-16 \mathrm{Mpa}$, hence this material may find useful application as scaffold for trabecular bone [26,27]. 


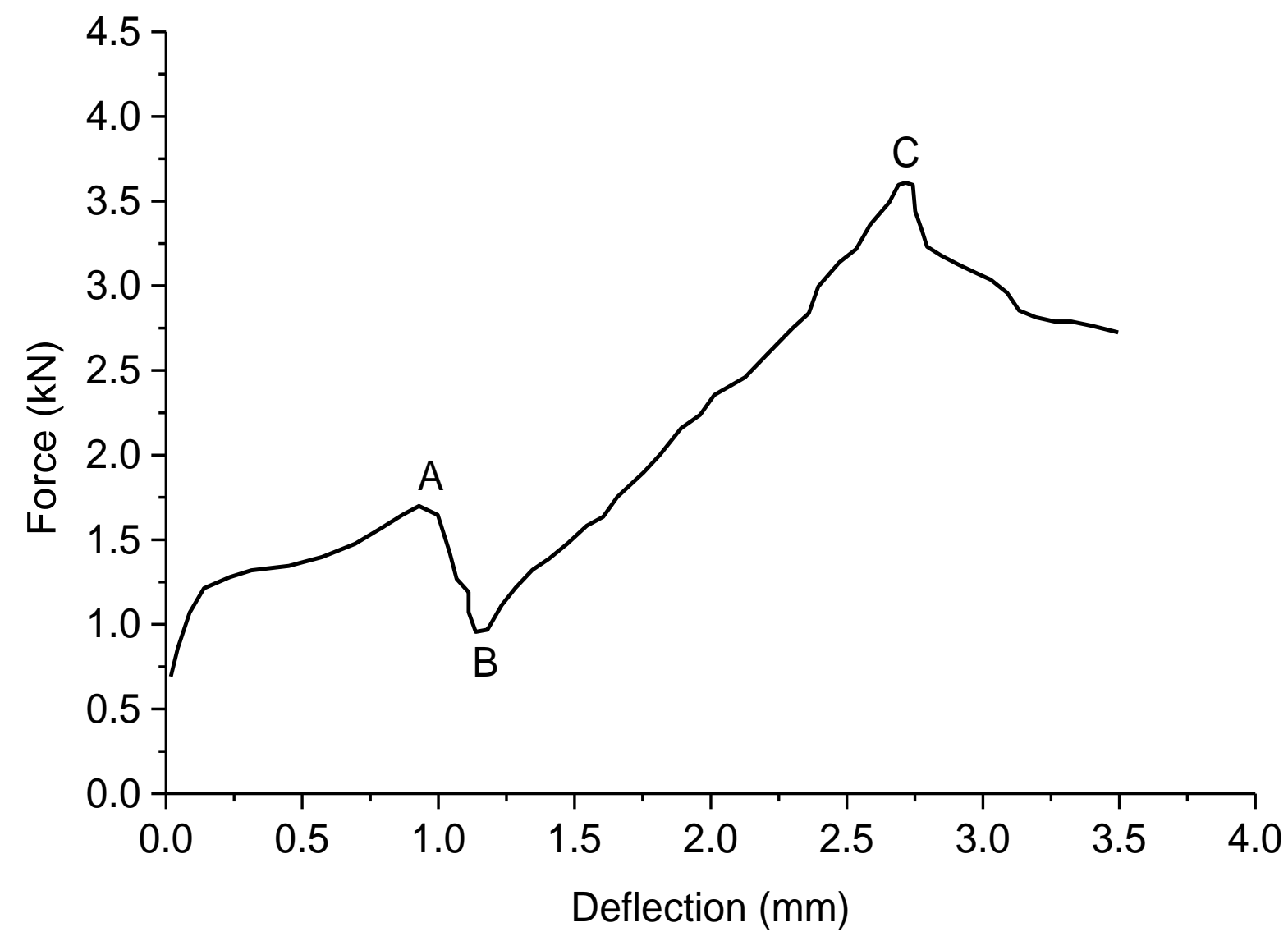

Figure 1. A four-stage force-deflection curve of the bioactive glass sintered at $950{ }^{\circ} \mathrm{C}$ for 3 hours with compression strength of $1.77 \mathrm{MPa}$.

\subsection{Morphology of glass}

The SEM micrographs depicting the morphology of the glass before and after immersion in SBF are presented in Figure 2. After sintering, the glass surface, as seen in Figure 2(a), contains plate-like particles ranging from 1.67-3.55 $\mu \mathrm{m}$ which appear to completely cover the surface of the glass providing large surface area and surface roughness with few visible micropores. The large surface area and rough texture are crucial to promote absorption of biological metabolites as well as attachment and proliferation of bone progenitor cell on the material [28-30]. The shape and arrangement of the glass particles suggests good densification of the material, which is important in maximizing the glass mechanical strength. The EDX spectrum indicates the presence of all the chemical components in the various percentages as prepared.

After immersion in SBF for 7 days, tiny balls of HA are seen on the surface of the glass with few agglomerates, Figure 2 (b). As observed in the micrograph, the HA does not completely cover the glass surface leaving exposed areas. This is confirmed by the EDX which could still detect the presence of $\mathrm{Si}$, but there is increase in the concentration of $\mathrm{Ca}$ and $\mathrm{P}$ due to formation of HA. As immersion period in SBF reached 14 days, the population of HA on the surface of the glass increased and became denser as observed in Figure 2(c). Accordingly, the EDX records low concentration for $\mathrm{Si}$, while $\mathrm{P}$ increases further due to increase apatite deposition. After 21 days of immersion in SBF, a thick apatite layer is seen in Figure 2(d) covering the glass surface to the extent that low $\mathrm{Si}$ detection is observed in the 
EDX. Furthermore, the concentration of $\mathrm{P}$ increased during this period resulting in a $\mathrm{Ca} / \mathrm{P}$ atomic ratio of 1.70 , which is close to the stoichiometric ratio of $\mathrm{Ca} / \mathrm{P}$ of 1.67 in $\mathrm{HA}$. Emergence of a small carbon peak is also visible in the EDX spectra after immersion for 21 days, which is an indication of the formation of HCA. The presence of $\mathrm{Mg}$ and $\mathrm{Cl}$ are also noticed in the EDX spectra, which can be attributed to insufficient rinse during extraction of the glass from the SBF solution after the various immersion periods.
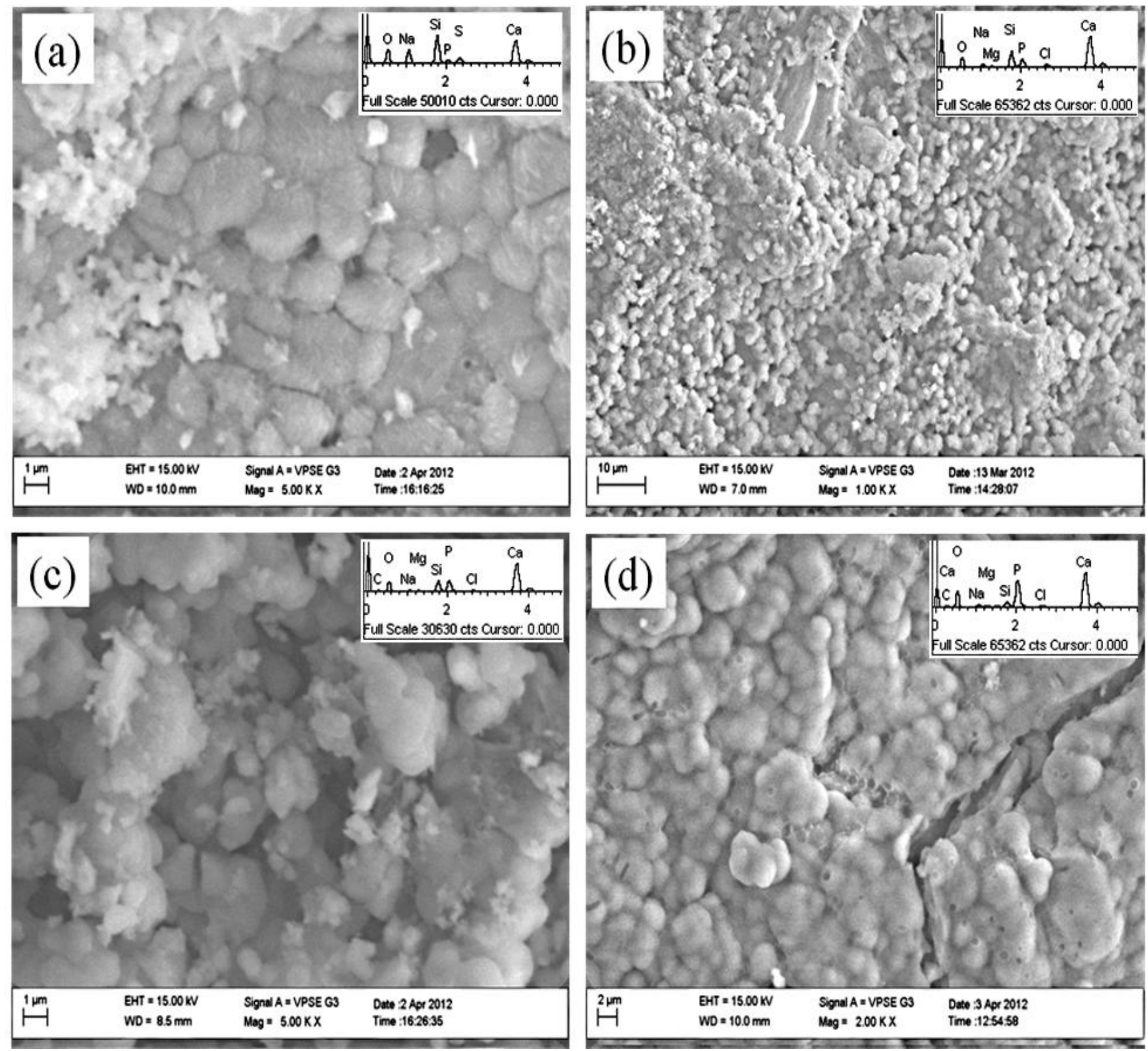

Figure 2. SEM micrographs with EDX insets showing the morphology of the glass before immersion in SBF (a) and after immersion for 7 days (b), 14 days (c) and 21 days showing the growth of apatite. 


\subsection{Diffraction patterns}

The X-ray spectra of the glass are shown in Figure 3. After sintering, the diffraction pattern contains sharp peaks which is identified as $\mathrm{Na}_{2} \mathrm{Ca}_{2} \mathrm{Si}_{3} \mathrm{O}_{9}$ according to the standard PDF \#22.1455 [21] and similar to those reported using TEOS for $45 \mathrm{~S} 5$ Bioglass $®$ at sintering temperature of $1000{ }^{\circ} \mathrm{C}$ for 2 hours [22,31]. Improved mechanical properties of $\mathrm{Na}$-containing glasses is attributed to the presence of $\mathrm{Na}_{2} \mathrm{Ca}_{2} \mathrm{Si}_{3} \mathrm{O}_{9}$ formed during sintering $[18,21]$. Thus, the plate-like microstructure observed earlier in Figure 2(a) and the mechanical strength of the glass could be as a result of the presence of this phase.

After soaking in SBF for 7-14 days, Figure 3(b-d) show HA peaks which match the standard PDF file, JCPDS \#9-0432 at $2 \theta 28.9^{\circ}, 2 \theta 31.7^{\circ}$, $2 \theta 33.9^{\circ}, 2 \theta 39.8^{\circ}$ and $46.7^{\circ}$ corresponding to the (h k f) planes at 210, 112, 300, 310 and 222 respectively [32,33]. It is also observed that the glass transformed to nearly amorphous phase after 14 days of immersion. After 21 days most of the $\mathrm{Na}_{2} \mathrm{Ca}_{2} \mathrm{Si}_{3} \mathrm{O}_{9}$ peaks had almost completely disappeared, the glass has become more amorphous, the HA peaks at $2 \theta 28.9^{\circ}$ and $2 \theta$ $39.8^{\circ}$ become sharper signalling the formation of crystalline HCA. This phase transformation is significant as the mechanically strong $\mathrm{Na}_{2} \mathrm{Ca}_{2} \mathrm{Si}_{3} \mathrm{O}_{9}$ crystalline structure is able to transform to amorphous, an indication that the glass is biodegradable in biological environments [18]. Hence this transformation corroborates previous findings $[21,22,34,35]$ that the two normally irreconcilable properties: mechanical competence and biodegradability can be combined in a single scaffold for clinical application.

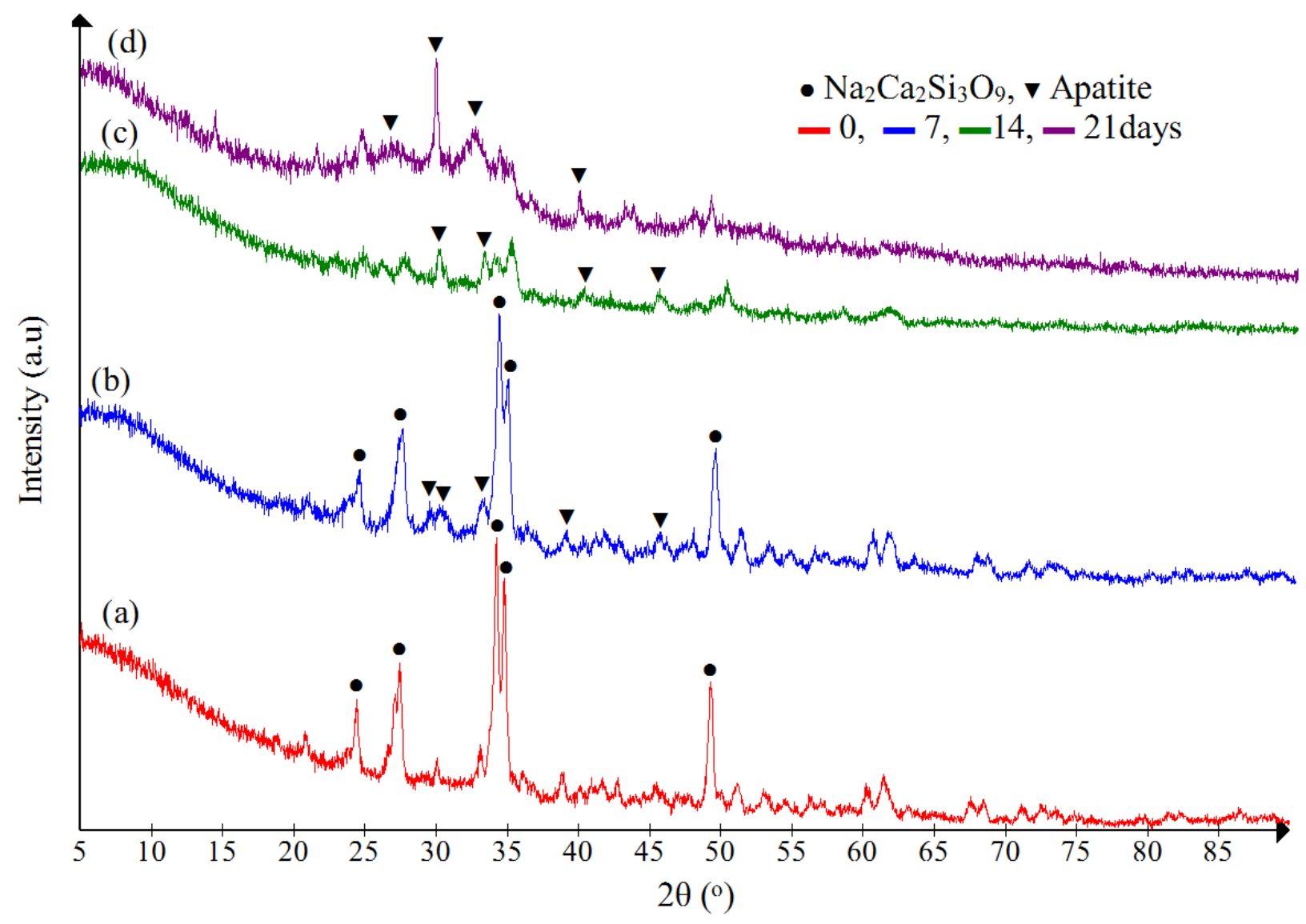

Figure 3. XRD spectra of the glass before immersion in SBF (a) and after immersion in SBF (b)-(d) showing phase transformation from crystalline to amorphous phase and formation of apatite. 


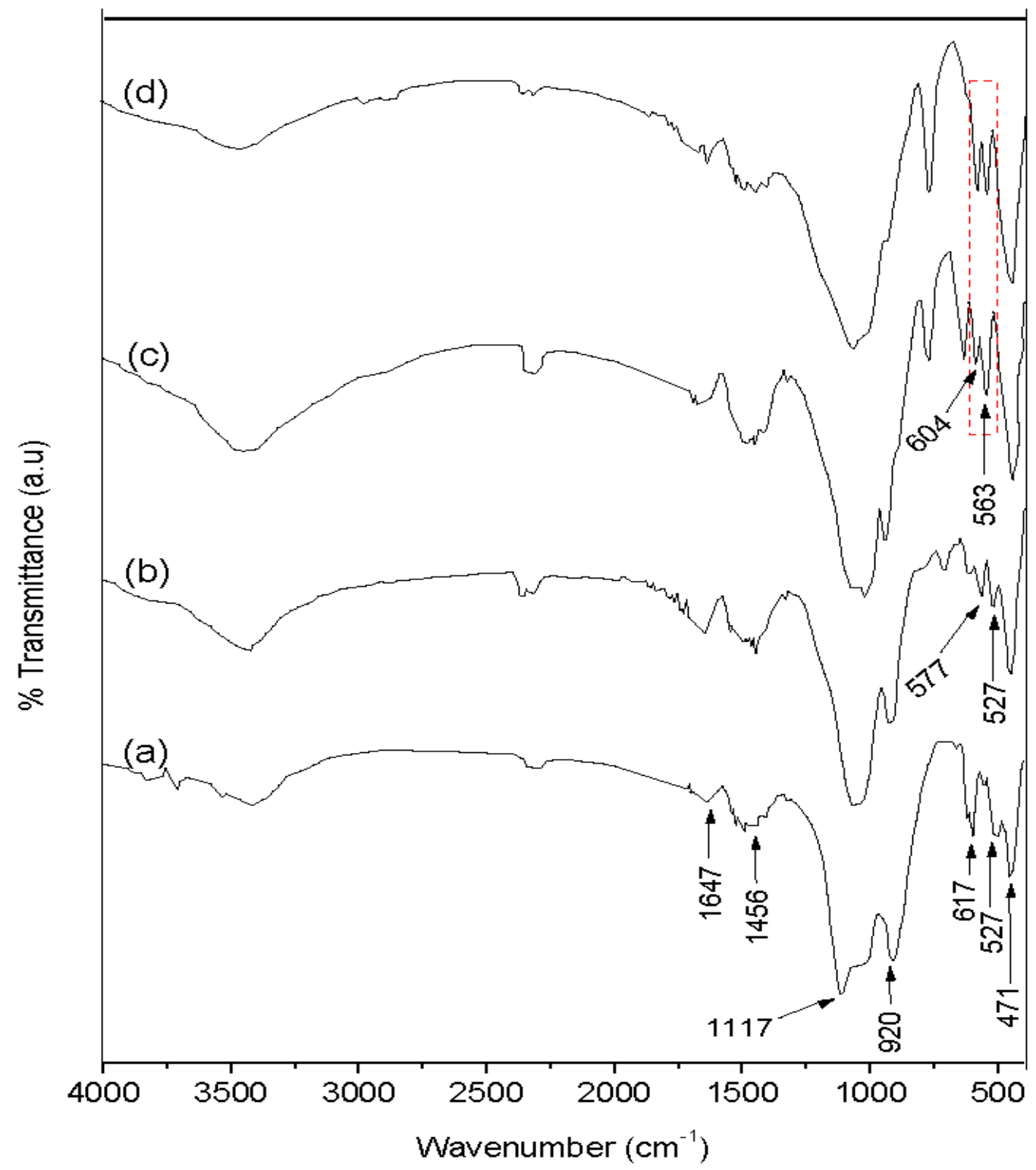

Figure 4. FTIR spectra of the glass before (a) and after immersion in SBF (b)-(d) showing apatite peaks. Red rectangular doted lines represent similar absorption modes.

\subsection{FTIR assessment of bonds}

The FTIR spectra of the bioactive glass before and after immersion in SBF are shown in Figure 4. As observed before immersion in SBF, Figure 4(a), there are prominent peaks at 3447, 1647, 1456, 1117, 920, 617, 527 and $471 \mathrm{~cm}^{-1}$. The broad band between $3300-3800 \mathrm{~cm}^{-1}$ centred at $3447 \mathrm{~cm}^{-1}$ is attributed to the presence of $\mathrm{OH}$ groups, which is further confirmed by the presence of water absorbed band around 1647 $\mathrm{cm}^{-1}$. The band around $1456 \mathrm{~cm}^{-1}$ is attributed to the absorption of carbonate group $\left(v_{3}\right)$, while the sharp peak at 1117 and $920 \mathrm{~cm}^{-1}$ are associated with $\mathrm{Si}-\mathrm{O}-\mathrm{Si}$ vibrational modes [35]. The peak at 617 and $527 \mathrm{~cm}^{-1}$ are due to the crystalline phase in the sample [22], and thus confirms the crystalline $\mathrm{Na}_{2} \mathrm{Ca}_{2} \mathrm{Si}_{3} \mathrm{O}_{9}$ earlier identified by the XRD result (Figure 3). The peak at $471 \mathrm{~cm}^{-1}$ is assigned to $\mathrm{Si}-\mathrm{O}-\mathrm{Si}$ bending vibrations. After 7 days, Figure 4(b), the peak at $1456 \mathrm{~cm}^{-1}$ becomes more intense, while a new peak emerges at 577 $\mathrm{cm}^{-1}$, considered for $\mathrm{P}-\mathrm{O}$ bending mode, which is characteristic of HA. The peak at $577 \mathrm{~cm}^{-1}$ splits into two modes at 604 and $569 \mathrm{~cm}^{-1}$ after 14 days 
as shown in Figure 4(c). This is characteristic of apatite crystalline phase [36], suggesting the incorporation of $\mathrm{CO}_{3}{ }^{2-}$ from the SBF solution into HA on the glass surface to form HCA. As immersion days increased to 21, Figure 4(d), the twin peaks at 604 and $563 \mathrm{~cm}^{-1}$ become more intense due to increase in density of HCA on the surface of the glass. This therefore confirms the EDX result in Figure 2(d) which showed the appearance of a small peak of $\mathrm{C}$ attributed to HCA formation.

\subsection{Reactivity of the glass in SBF}

The reactivity of the glass evaluated from $\mathrm{pH}$ changes in SBF for the first 14 days is presented in Figure 5. There is a steep rise in $\mathrm{pH}$ from the initial 7.4 to 8.6 during the first 4 days, which shows the ability of the glass to exchange alkali and alkaline earth ions $\left(\mathrm{Na}^{+}\right.$and $\left.\mathrm{Ca}^{2+}\right)$ rapidly with $\mathrm{H}^{+}$or $\mathrm{H}_{3} \mathrm{O}^{+}$ions in the $\mathrm{SBF}$. This is in agreement with the first stage of the reaction of bioactive glasses in biological fluids [37] and also signifies the degradation capacity of the glass. After 4 days the $\mathrm{pH}$ increases slowly until 6 days because part of the released $\mathrm{Ca}$ from the glass is used to form $\mathrm{CaO}-\mathrm{P}_{2} \mathrm{O}_{5}$, thus decreasing the release rate. Consequently $\mathrm{HA}$ precipitation occurred on the glass surface as shown earlier (Figure 2(b)). As the soaking time reached 7 days the $\mathrm{pH}$ increase slowed further as more $\mathrm{Ca}$ is withdrawn from the SBF solution to develop more HA layers on the surface of the glass, confirming the increase in density of HA (Figure 2(c)). Finally, the $\mathrm{pH}$ reaches a saturated value of 9.3 after 13 days without increasing any further due to crystallization of HCA, whose mechanism is explained elsewhere [38]. Formation of HCA had earlier been identified from the results of EDX, XRD and FTIR in Figures 2(d), 3(d) and 4(d) respectively.

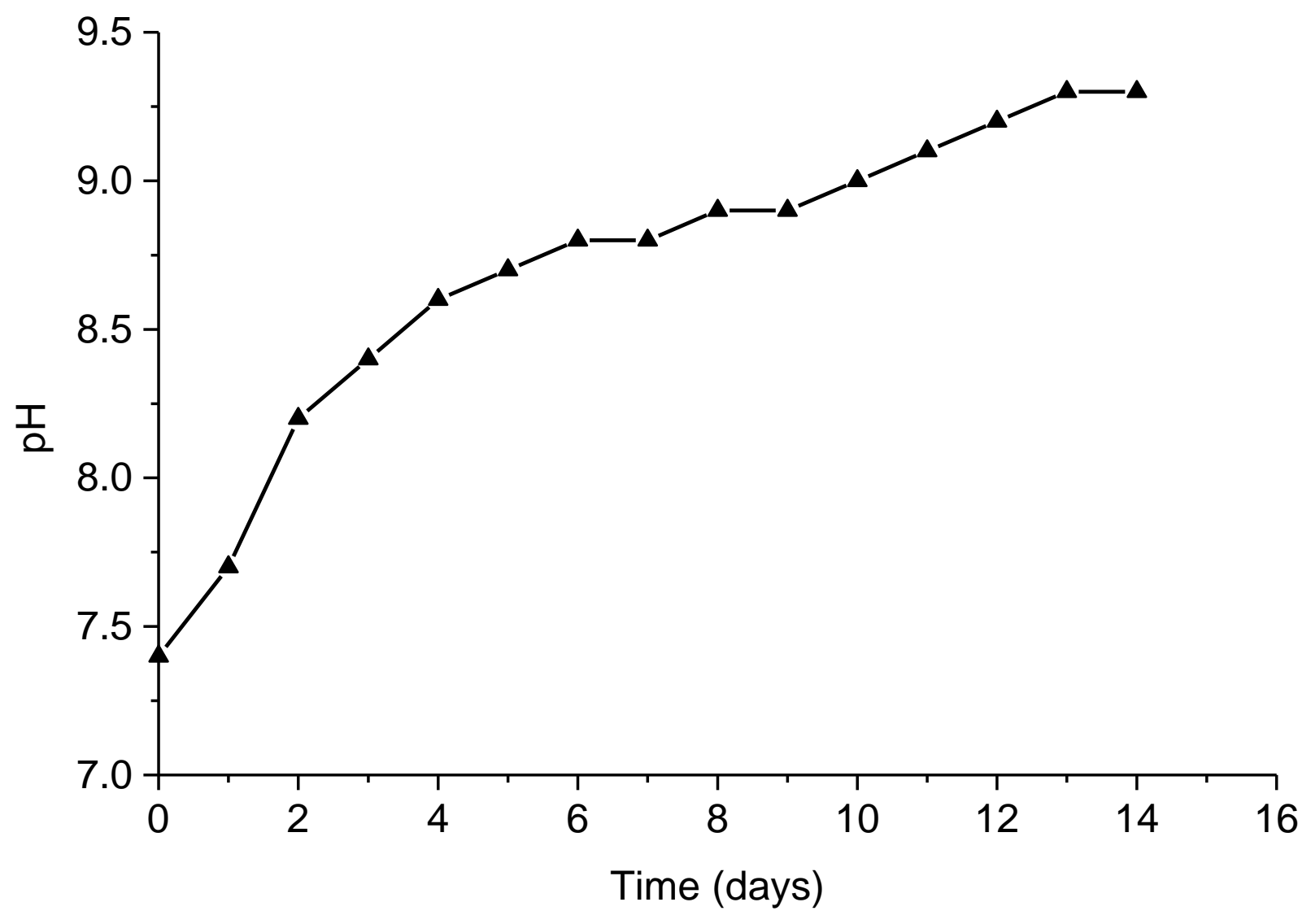

Figure 5. $\mathrm{pH}$ changes of the glass for the first 14 days of immersion in SBF. 


\section{Conclusions}

A highly bioactive $\mathrm{SiO}_{2}-\mathrm{Na}_{2} \mathrm{O}-\mathrm{CaO}-\mathrm{P}_{2} \mathrm{O}_{5}$ formed using sand as starting material and sintered at $950{ }^{\circ} \mathrm{C}$ for $3 \mathrm{~h}$ gave a compression strength of $1.77 \mathrm{Mpa}$. The mechanical properties was attributed to proper densification and the presence of $\mathrm{Na}_{2} \mathrm{Ca}_{2} \mathrm{Si}_{3} \mathrm{O}_{9}$ crystalline phase. When immersed in SBF, HA and HCA were identified in the material while the crystalline $\mathrm{Na}_{2} \mathrm{Ca}_{2} \mathrm{Si}_{3} \mathrm{O}_{9}$ transformed to amorphous phase. The mechanical properties and transformation of the glass from crystalline to amorphous within 14 days in SBF indicates degradability and is an important property required to serve as scaffold for tissue engineering of trabecular bone. Furthermore the use of sand as cheap starting material instead of TEOS for this type of study could enhance commercialization of glasses in the $\mathrm{SiO}_{2}-\mathrm{Na}_{2} \mathrm{O}-$ $\mathrm{CaO}-\mathrm{P}_{2} \mathrm{O}_{5}$ system.

\section{Acknowledgements}

The authors express their gratitude to Sheda Science and Technology Complex (SHESTCO), Abuja and Redeemers University (RUN), Ede, Nigeria, for the SEM/EDX and FTIR Characterization of samples from this work.

\section{References}

1. Rezwan, K.; Chen, Q. Z.; Blaker, J. J.; Boccaccini, A. R. Biodegradable and bioactive porous polymer/inorganic composite scaffolds for bone tissue engineering, Biomaterials 2006, 27(18), 3413-3431.

DOI: 10.1016/j.biomaterials.2006.01.039

2. Vitale-Brovarone, C.; Miola, M.; Balagna, C.; Verné, E. 3D-glass-ceramic scaffolds with antibacterial properties for bone grafting, Chem. Eng. J. 2008, 137(1), 129-136. DOI: 10.1016/j.cej.2007.07.083

3. Karageorgiou, V.; Kaplan, D. Porosity of 3D biomaterial scaffolds and osteogenesis,
Biomaterials 2005, 26(27), 5474-5491. DOI: 10.1016/j.biomaterials.2005.02.002

4. Smith, I. O.; Ren, F.; Baumann, M. J.; Case, E. D. Confocal laser scanning microscopy as a tool for imaging cancellous bone, J. Biomed. Mater. Res. B Appl. Biomater. 2006, 79(1), 85-92. DOI: $10.1002 / \mathrm{jbm} . b .30529$

5. Woodward, J. R.; Hilldore, A. J.; Lan, S. K.; Park, C. J.; Morgan, A.W.; Eurell, J. A.;Clark, S. G.; Wheeler, M. B.; Jamison, R. D.; Wagoner Johnson, A.J. The mechanical properties and osteoconductivity of hydroxyapatite bone scaffolds with multiscale porosity, Biomaterials 2007, 28(1), 4554. DOI: 10.1016/j.biomaterials.2006.08.021

6. Vitale-Brovarone, C.; Baino, F.; Verné, E. High strength bioactive glass-ceramic scaffolds for bone regeneration, J. Mater. Sci. Mater. Med. 2009, 20(2), 643-653. DOI: $10.1007 / \mathrm{s} 10856-008-3605-0$

7. Hench, L. L. Bioceramics, J. Am. Ceram. Soc. 1998, 81(7), 1705-1728. DOI: 10.1111/j.1151-2916.1998.tb02540.x

8. Peitl, O.; LaTorre, G. P.; Hench, L. L. Effect of crystallization on apatite-layer formation of bioactive glass 45S5, J. Biomed. Mater. Res. 1996, 30(4), 509-514. DOI: $10.1002 /($ SICI) 1097-4636(199604)30:4 $<509:$ :AID-JBM9>3.0.CO;2-T

9. Aly, AF.; Eldelsouky, AS.; Eid, K. A. M. Evaluation, characterization of ceramic scaffold and nano-gold loaded ceramic scaffold for bone tissure engineering, Am. J. Biomed. Sci. 2012, 4(4), 316-326. DOI: $10.5099 /$ aj 120400316

10. Xynos, I. D.; Edgar, A. J.; Buttery, L. D. K.; Hench, L. L.; Polak, J. M. Gene- expression profiling of human osteoblasts following treatment with the ionic products of Bioglass ${ }^{\circledR}$ 45S5 dissolution, J. Biomed. Mater. Res. 2001, 55(2), 151-157. DOI: $10.1002 / 1097-4636(200105) 55: 2<151::$ AID-JBM1001>3.0.CO;2-D

11. Xynos, I. D.; Hukkanen, M. V. J.; Batten, J. J.; Buttery, L. D.; Hench, L. L.; Polak, J. M. 
Bioglass ${ }^{\circledR} \quad 45 \mathrm{~S} 5$ stimulates osteoblast turnover and enhances bone formation in vitro: Implications and applications for bone tissue engineering, Calcif. Tissue Int. (2000), 67(4),

321-329.

DOI: $10.1007 / \mathrm{s} 002230001134$

12. Hench, L. L. Genetic design of bioactive glass, J. Eur. Ceram. Soc. 2009, 29(7), 12571265.

DOI: 10.1016/j.jeurceramsoc.2008.08.002

13. Jell, G.; Stevens, M. M. Gene activation by bioactive glasses, J. Mater. Sci. Mater. Med. 2006, 17(11), 997-1002. DOI: $10.1007 / \mathrm{s} 10856-006-0435-9$

14 Hench, L. L. Abstracts of Papers of the American Chemical Society, vol. 173, 1977, p. 10.

15. Hench, L. L.; Pantano, C. G.; Buscemi, P. J.; Greenspan, D. C. Analysis of bioglass fixation of hip prosthesis, J. Biomed. Mater. Res. 1977, 11(2), 267-282. DOI: $10.1002 / \mathrm{jbm} .820110211$

16. Hench, L. L.; Paschall, H. F.; Paschall, M.; McVey, J. Histological responses at bioglass and bioglass-ceramic interfaces, Am. Ceram. Soc. Bull. 1973, 52(4), 432-432.

17. Boccaccini, A. R. Ceramics, Hench, L. L., Jones J. R. Ed.; Woodhead Publishing Limited CRC Press, 2005; pp 26-36.

18. Boccaccini, A. R.; Chen, Q.; Lefebvre, L.; Gremillard, L.; Chevalier, J. Sintering, crystallisation and biodegradation behaviour of Bioglass-derived glass-ceramics, Faraday Discuss. 2007, 136, 27-44. DOI: $10.1039 / \mathrm{b} 616539 \mathrm{~g}$

19. Thompson, I. D.; Hench, L. L. Mechanical properties of bioactive glasses, glassceramics and composites, Proc. Inst. Mech. Eng. Part H-J. Eng. Med. 1998, 212(2),127136. DOI: $10.1243 / 0954411981533908$

20. Du, R.; Chang, J. Preparation and characterization of bioactive sol-gel-derived $\mathrm{Na}_{2} \mathrm{Ca}_{2} \mathrm{Si}_{3} \mathrm{O}_{9}$, J. Mater. Sci. Mater. Med. 2004, 15(12), 1285-1289. DOI: $10.1007 / \mathrm{s} 10856-004-5736-2$

21. Chen, Q. Z.; Thompson, I. D.; Boccaccini, A.
R. 45S5 Bioglasss-derived glass-ceramic scaffolds for bone tissue engineering, Biomaterials 2006, 27(11), 2414-2425. DOI: 10.1016/j.biomaterials.2005.11.025

22. Chen, Q.-Z.; Yuan, L. Y.; Jin, L.-Y.; Quinn, J. M. W.; Komesaroff, P. A. A new sol-gel process for producing $\mathrm{Na} 2 \mathrm{O}$-containing bioactive glass ceramics, Acta Biomater. 2010, 6(10), 4143-4153. DOI: $10.1016 /$ j.actbio.2010.04.022

23. Essien, E. R.; Adams, L. A.; Shaibu, R. O.; Olasupo, I. A.; Aderemi, O. Economic route to sodium-containing silicate bioactive glass scaffold, Open J. Regen. Med. 2012, 1(3), 33-40. DOI: 10.4236/ojrm.2012.13006

24. Cao, W.; Hench, L. L. Bioactive materials, Ceram. Int. 1996, 22(6), 493-507. DOI: $10.1016 / 0272-8842(95) 00126-3$

25. Kokubo, T.; Takadama, H. How useful is SBF in predicting in vivo bone bioactivity? Biomaterials 2006, 27(15), 2907-2915. DOI: 10.1016/j.biomaterials.2006.01.017

26. Jones, J. R.; Lee, P. D.; Hench L. L, Hierarchical porous materials for tissue engineering, Phil. Trans. R. Soc. A. 2006, 364(1838), 263-281. DOI: $10.1098 /$ rsta.2005.1689

27. Wu, Y. Z.; Hill, R. G.; Yue, S.; Nightingale, D.; Lee, P. D. Jones, J. R Melt-derived bioactive glass scaffolds produced by a gelcast foaming technique, Acta Biomater. 2011, 7(4), 1807-1816. DOI: $10.1016 /$ j.actbio.2010.11.041

28. Deligianni, D. D.; Katsala, N. D.; Koutsoukos, P. G.; Missirlis, Y. F. Effect of surface roughness of hydroxyapatite on human bone marrow cell adhesion, proliferation, differentiation and detachment strength, Biomaterials 2001, 22(1), 87-96. DOI: $10.1016 / \mathrm{S} 0142-9612(00) 00174-5$

29. Hench, L. L. Sol-gel materials for bioceramic applications, Curr. Opin. Solid State Mater. 1997 , $2(5)$ 604-610. DOI: $10.1016 / \mathrm{S} 1359-0286(97) 80053-8$

30. Eid, K.; Eldesouky, A.; Fahmy, A.; Shahat, A.; AbdElaal, R. Calcium phosphate loaded 
with platinum nanoparticles for bone allograft, Am. J. Biomed. Sci. 2013, 5(4), 242-249. DOI: 10.5099/aj130400242

31. Chen, Q.-Z.; Thouas, G. A. Fabrication and characterization of sol-gel derived 45S5 Bioglass-ceramic scaffolds, Acta Biomater. 2011, 7(10), 3616-3626. DOI: $10.1016 /$ j.actbio.2011.06.005

32. Lin, K. S. K.; Yao-Hung, T.; Mou, Y.; YuChuan, H.; China-Min, Y.; Chan, J. C. C.Mechanistic study of apatite formation on bioactive glass surface using 31P solid-state NMR spectroscopy, Chem. Mater. 2005, 17(17), 4493-4501.DOI: 10.1021/cm050654c

33. Bingöl, O. R,; Durucan, C. Hydrothermal synthesis of hydroxyl apatite from calcium sulphate hemihydrates, Am. J. Biomed. Sci. 2012, 4(1), 50-59.DOI: 10.5099/aj120100050

34. Peitl, O.; Zanotto, E. D.; La Torre, G. P.; Hench, L. L. Bioactive ceramics and method of preparing bioactive ceramics, Patent WO/1997/041079, November 06, 1997.

35. Peitl, O.; Zanotto, E.D.; Hench, L.L. Highly bioactive $\mathrm{P}_{2} \mathrm{O}_{5}-\mathrm{Na}_{2} \mathrm{O}-\mathrm{CaO}-\mathrm{SiO}_{2}$ glass-
Ceramics, J. Non-Cryst. Solids 2001, 292(1$3)$ 115-126. DOI: 10.1016/S00223093(01)00822-5

36. Oliveira, J. M.; Correia, R. N.; Fernandes, M. $\mathrm{H}$. Effects of $\mathrm{Si}$ speciation on the in vitro bioactivity of glasses. Biomaterials 2002, 23(2), 371-379. DOI: $10.1016 / \mathrm{S} 0142-9612(01) 00115-6$

37. Clupper, D. C.; Mecholsky J. J. Jr.; LaTorre, G. P.; Greenspan, D. C. Sintering temperature effects on the in vitro bioactive response of tape cast and sintered bioactive glass-ceramic in Tris buffer, J. Biomed. Mater. Res. 2001, 57(4), 532-540. DOI: $\quad 10.1002 / 1097-4636(20011215) 57: 4$ $\leq 532:: A I D-J B M 1199>3.0 . C O ; 2-3$

38. Hench, L. L.; Splinter, R. J.; Allen, W. C.; Greenlee, T. K. Bonding mechanisms at the interface of ceramic prosthetic materials, J. Biomed. Mater. Res. 1971, 5(6), 117-141. DOI: $10.1002 / \mathrm{jbm} .820050611$ 